\title{
A putative role for anti-Müllerian hormone (AMH) in optimising ovarian reserve expenditure
}

\author{
Michael W Pankhurst
}

Department of Anatomy, School of Biomedical Sciences, University of Otago, Dunedin, New Zealand

Correspondence should be addressed to M W Pankhurst Email

michael.pankhurst@otago. ac.nz

\begin{abstract}
The mammalian ovary has a finite supply of oocytes, which are contained within primordial follicles where they are arrested in a dormant state. The number of primordial follicles in the ovary at puberty is highly variable between females of the same species. Females that enter puberty with a small ovarian reserve are at risk of a shorter reproductive lifespan, as their ovarian reserve is expected to be depleted faster. One of the roles of anti-Müllerian hormone (AMH) is to inhibit primordial follicle activation, which slows the rate at which the ovarian reserve is depleted. A simple interpretation is that the function of $\mathrm{AMH}$ is to conserve ovarian reserve. However, the females with the lowest ovarian reserve and the greatest risk of early reserve depletion have the lowest levels of $\mathrm{AMH}$. In contrast, $\mathrm{AMH}$ apparently strongly inhibits primordial follicle activation in females with ample ovarian reserve, for reasons that remain unexplained. The rate of primordial follicle activation determines the size of the developing follicle pool, which in turn, determines how many oocytes are available to be selected for ovulation. This review discusses the evidence that AMH regulates the size of the developing follicle pool by altering the rate of primordial follicle activation in a context-dependent manner. The expression patterns of AMH across life are also consistent with changing requirements for primordial follicle activation in the ageing ovary. A potential role of $\mathrm{AMH}$ in the fertility of ageing females is proposed herein.
\end{abstract}

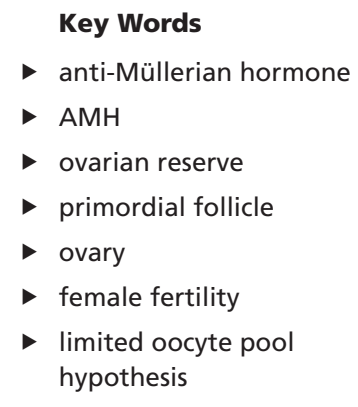

Journal of Endocrinology (2017) 233, R1-R13

\section{Introduction}

The mammalian ovary has a finite number of oocytes that are formed in foetal development (Monniaux et al. 2014). During embryonic development, primordial germ cells migrate from the primitive streak through the endoderm to the genital ridge where they differentiate into oogonia while the foetal ovary forms (Richardson \& Lehmann 2010). After the initial burst of oogonial proliferation, the cells begin meiosis, but the process is arrested in prophase-I (Jones \& Lane 2013). The arrested oocytes initially form clusters and then become encapsulated in pre-granulosa cells, forming a structure known as the primordial follicle, which represents a dormant, non-growing state (Kerr et al. 2013). Primordial follicle activation is the first step in the development and growth phase that eventually leads to the generation of a preovulatory follicle capable of releasing a viable oocyte (McGee \& Hsueh 2000). Primordial follicles can become activated soon after their initial formation and it is not known why some follicles become activated early in life, whereas others are able to remain dormant for months, years or decades (Zhang \& Liu 2015). The rate 
of primordial follicle activation exceeds the rate at which mature oocytes are ovulated, with the excess developing follicles being removed via a process known as atresia (McGee \& Hsueh 2000, Monniaux et al. 2014).

The size of the primordial follicle pool (the ovarian reserve) declines throughout life, hence, is likely to be a key determinant of the reproductive lifespan. This is particularly true for humans, orca and short-finned pilot whales, all of which experience ovarian reserve depletion and menopause, many years before the end of their natural lifespan (Marsh \& Kasuya 1986, Brent et al. 2015, Depmann et al. 2015). Menopause is rare throughout the animal kingdom, but increasing evidence suggests that reproductive senescence is common (Packer et al. 1998, Nussey et al. 2013). In humans, female infertility occurs approximately 10 years prior to menopause, with subfertility becoming evident in the early 30s (te Velde \& Pearson 2002, Broekmans et al. 2009, Eijkemans et al. 2014). This suggests that reproductive senescence occurs well in advance of depletion of the ovarian reserve. Little is known about how the ovary regulates the rate at which the primordial follicle reserve declines and the precise mechanisms that determine the length of the reproductive lifespan. This review focuses on an emerging regulator of primordial follicle activation, anti-Müllerian hormone $(\mathrm{AMH})$, which has evolutionarily conserved functions in the mammalian ovary. The possibility that $\mathrm{AMH}$ and other primordial follicle activation regulators play a role in regulating female fertility across the lifespan will be discussed.

\section{Anti-Müllerian hormone expression in the ovary}

Anti-Müllerian hormone (AMH) is a glycoprotein of the TGF $\beta$ superfamily, a large and diverse family of growth factors and hormones (Shi \& Massague 2003). In the ovary, AMH is primarily produced in the granulosa cells of developing, nonatretic follicles. Granulosa cells do not express AMH in the primordial stage, but expression becomes evident after follicle activation and transition to the primary stage (Baarends et al. 1995, Gruijters et al. 2003, Weenen et al. 2004). Expression of AMH increases as the follicle develops through the preantral and small antral stages in humans (Weenen et al. 2004). Similar patterns occur in non-human primates (Modi et al. 2006), mice (Gruijters et al. 2003), rats (Ueno et al. 1989, Hirobe et al. 1994, Baarends et al. 1995), Siberian hamsters (Shahed \& Young 2013), cows (Monniaux et al. 2012), goats (Monniaux et al. 2012, Rocha et al. 2016), sheep (Bezard et al. 1987, Campbell et al. 2012) and brushtail possums (Juengel et al. 2002). AMH expression declines as follicles progress through the large antral stage of folliculogenesis, with little AMH being produced in preovulatory follicles (Ueno et al. 1989, Weenen et al. 2004, Jeppesen et al. 2013). However, AMH expression remains elevated in the cumulus granulosa cells of large follicles until immediately prior to ovulation (Ueno et al. 1989, Hirobe et al. 1994, Monniaux et al. 2012, Merhi et al. 2013). AMH expression is negligible in atretic follicles (Weenen et al. 2004).

AMH signalling requires simultaneous binding to one of three type-1 receptors (ACVR1, BMPR1A or BMPR1B) and the AMH type-2 receptor (AMHR2) (Mishina et al. 1996, Gouedard et al. 2000, Clarke et al. 2001, Visser et al. 2001, Orvis et al. 2008, Sedes et al. 2013). AMH is unique among the TGF $\beta$ superfamily, as it is the only known member that does not share its type 2 receptor with other ligands. AMHR2 in the ovary is expressed in granulosa cells in a pattern that matches AMH; high levels in the early stages of developing follicles and declining expression in large antral stages (Baarends et al. 1995). In situ hybridisation suggests that Amhr2 mRNA is not expressed in the granulosa cells of primordial follicles (Baarends et al. 1995), but it has been detected by qPCR in the smallest class of follicles isolated from human ovaries, which are likely to contain both primordial and primary follicles (Rice et al. 2007, Kristensen et al. 2013). The effects of AMH on primordial follicles have been replicated extensively (described below), but the signalling mechanism remains unclear, as there is debate as to whether primordial follicles express low levels of AMHR2 or none at all. A functional experiment suggests that the effect is AMHR2-dependent (Gigli et al. 2005), but the mechanism of AMH action on primordial follicles still needs to be elucidated.

$\mathrm{AMH}$ expression has been observed in the ovary, brain, placenta and uterus (Wang et al. 2005, 2009, Novembri et al. 2015, Cimino et al. 2016), but serum levels diminish rapidly after oophorectomy indicating that the ovary is the primary contributor of circulating AMH in females (Griesinger et al. 2012). AMH levels show minimal diurnal or circadian variation in women (Bungum et al. 2011), and variation during the ovarian cycle is subtle (reviewed by La Marca et al. 2013, also see Kissell et al. 2014, Gnoth et al. 2015, Hadlow et al. 2016, Lambert-Messerlian et al. 2016, Pankhurst \& Chong 2016). This contrasts with variation in levels of other ovarian hormones (Groome et al. 1996). Longitudinal experiments

Published by Bioscientifica Ltd. 
suggest that substantive changes in AMH levels only become apparent when examined over multiple years (de Vet et al. 2002), with these changes being summarised

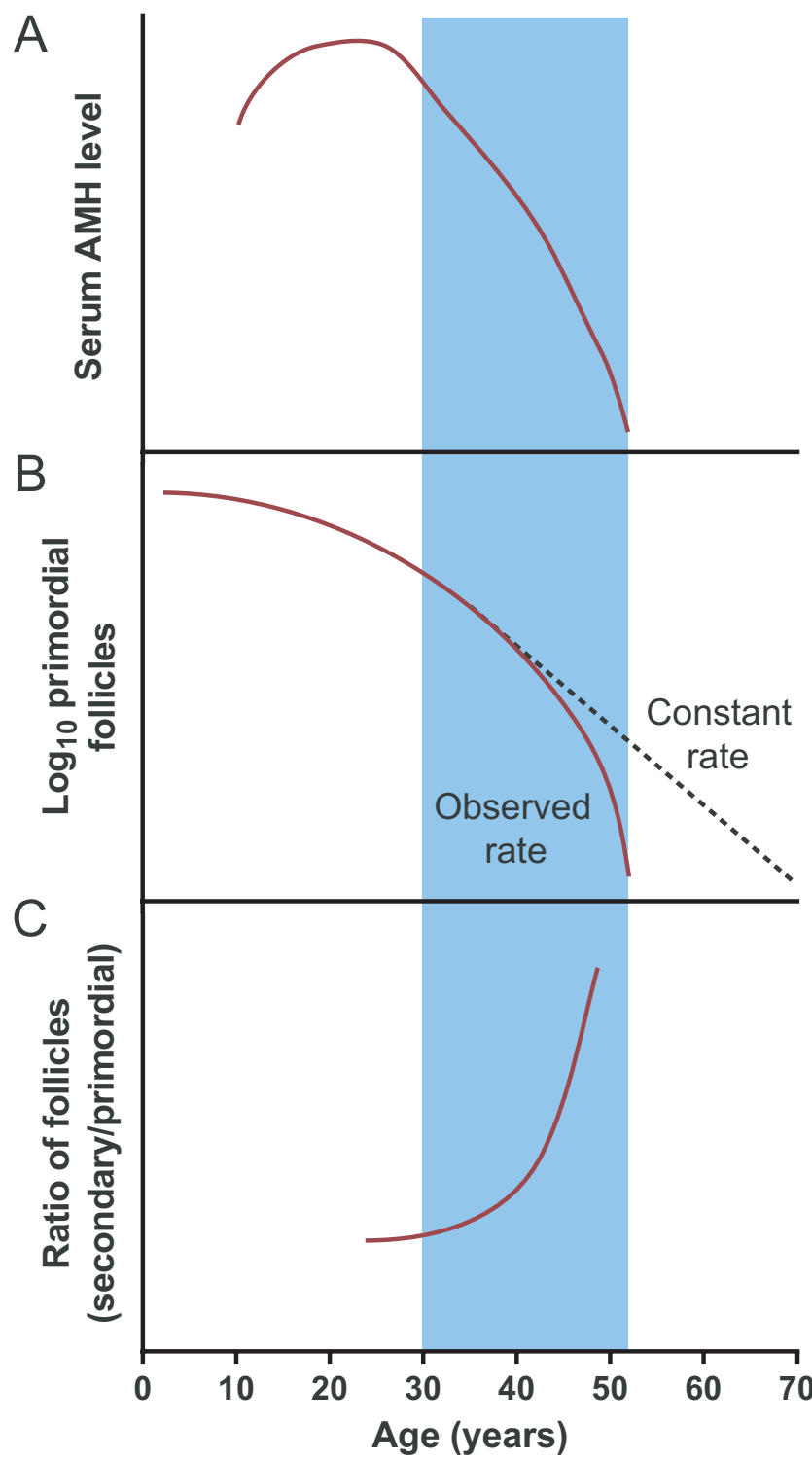

Figure 1

Lifelong AMH profiles are consistent with age-related changes in primordial follicle depletion rates in women. The blue band encompasses the time between the initial age at which declining fertility is observed in the population and the average age at menopause. (A) Serum AMH levels in women begin to decline from the mid-twenties which continues until menopause (based on data from Kelsey et al. 2011, Seifer et al. 2011). (B) The remaining number of primordial follicles declines throughout life with an acceleration in the rate of loss later in reproductive life. The projected trajectory of primordial follicle loss if rate of decline remained constant is displayed by the dashed line (based on data from Faddy et al. 1992, Wallace \& Kelsey 2010, Depmann et al. 2015). (C) The ratio of secondary follicles to primordial follicles increases with age indicating that primordial follicle activation rates increase, relative to the size of the remaining follicle pool (based on data from Faddy and Gosden 1995). in Fig. 1A. Female serum AMH levels are low at birth but slowly increase throughout early life, reaching a peak at about 25 years of age (Hagen et al. 2010, Fleming et al. 2012). AMH levels subsequently decline, with little or no AMH being detectable after menopause; a time when the ovary is depleted of primordial and developing follicles (Seifer et al. 2011, Chong et al. 2012, de Kat et al. 2016).

The action of hormones and growth factors is determined by their concentration at the target cell's receptors. The function of a hormone or growth factor is often related to the timescale over which concentrations vary. The slow changes in AMH levels suggest that it regulates the long-term processes, across the lifespan. Correlation studies suggest that the size of the developing follicle pool is the primary determinant of AMH concentrations in women (Fanchin et al. 2003, Hansen et al. 2011, Bentzen et al. 2013). In essence, the AMH-responsive cells (outside of early developing follicles) are being regulated by the size of the developing follicle pool. Plasma AMH levels also correlate with primordial follicle numbers in rats (Erbas et al. 2014), which probably occurs due to a strong association between primordial and developing follicle counts (Hansen et al. 2011). Women who begin their life with a low antral follicle count/ovarian reserve tend to experience low AMH levels relative to other women of similar age. This relationship is observed in multiple species including mice, cows, goats and horses (Kevenaar et al. 2006, Monniaux et al. 2012, Batista et al. 2014, Claes et al. 2015).

It is worth mentioning that AMH has ovarian functions that are unrelated to primordial follicle activation, such as modulation of FSH sensitivity in granulosa cells (reviewed by Visser \& Themmen 2014). In this context, AMH signalling is intrafollicular and is not subject to the same age-related changes in concentration that are observed in circulation and the extrafollicular ovarian environment (discussed below). At present, intrafollicular-autocrine AMH signalling does not appear to be essential for reproductive function, as $\mathrm{AMH}$ null-mutant $\left(\mathrm{AMH}^{--}\right)$mice only show altered ovulatory responses under supraphysiological doses of FSH (Visser et al. 2007). This review does not discuss the intrafollicular-autocrine functions of $\mathrm{AMH}$ further, but research into this area is ongoing.

\section{AMH is a paracrine regulator of primordial follicle activation}

Primordial follicles are capable of transitioning to the primary follicle stage soon after their formation; yet, a

Published by Bioscientifica Ltd. 
proportion remains quiescent until late in reproductive life (Adhikari \& Liu 2009). Numerous regulators that induce follicle activation have been identified including KITligand, epidermal growth factor, fibroblast growth factor 2 and 7, platelet-derived growth factor, bone morphogenetic protein 4 and 7, growth and differentiation factor 9, neurotrophin 3, brain-derived neurotrophic factor, glial-derived neurotrophic factor, insulin, interleukin 16, leukaemia inhibitory factor and gremlin (Dole et al. 2008, Adhikari \& Liu 2009, McLaughlin \& McIver 2009, Nilsson et al. 2009, 2014, Feeney et al. 2014). The inhibitors of primordial activation that have been described to date include CXCL12, oestradiol, growth hormone, Hippo signalling and AMH (Adhikari \& Liu 2009, McLaughlin \& McIver 2009, Hsueh et al. 2015).

Studies in female $\mathrm{AMH}^{-/-}$mice demonstrate that the loss of AMH accelerates the activation rate of primordial follicles leading to premature depletion of the ovarian reserve, akin to human menopause (Durlinger et al. 1999). Accordingly, $\mathrm{AMH}^{-/-}$mice have enlarged pools of preantral and small antral follicles, but concomitant increases in atresia have a correcting influence on large antral follicle counts, which are equivalent to counts in wild-type mice (Durlinger et al. 1999, Visser et al. 2007). Conservation of the ovarian reserve after injection of recombinant AMH into young mice has also been observed (Hayes et al. 2016). Exogenous application of AMH inhibits primordial follicle activation in explant cultures of human, rat, mouse and goat ovary tissue (Durlinger et al. 2002, Gigli et al. 2005, Carlsson et al. 2006, Nilsson et al. 2007, 2014, Rocha et al. 2016). Similar experiments have shown that positive regulators of primordial follicle activation such as KIT-ligand, fibroblast growth factor 2, 7 or gremlin antagonise the effects of AMH (Nilsson et al. 2007, 2014). This suggests that primordial follicle activation involves a balance between activation-promoting and activationinhibiting factors.

Not all studies support AMH-mediated inhibition of primordial follicle activation. Schmidt and coworkers (Schmidt et al. 2005) reported that AMH caused an increase in the rate of primordial activation in human ovarian cortex explant cultures. It has been suggested that this difference occurred due to the culture period of 4 weeks, which is longer than the 2- to 10-day period used in other studies (van Houten et al. 2010). A recent report suggested that AMH inhibits primordial follicle assembly in neonatal rat organ cultures (Nilsson et al. 2011), which could affect the interpretation of primordial follicle activation experiments involving AMH. However, it was not clear whether $\mathrm{AMH}$ affected follicle formation or short-term survival of oocytes that had failed to assemble into follicles (Nilsson et al. 2011). An inherent limitation of ovary explant/organ cultures is the inability to distinguish interactions between primordial follicle activation, survival and assembly. In vivo, primordial follicle numbers are similar in $\mathrm{AMH}^{+/+}$and $\mathrm{AMH}^{-/-}$mice prior to puberty (Durlinger et al. 1999), which is the phase of life when differences in follicle assembly and survival should be most apparent (Tingen et al. 2009). This is the strongest evidence that AMH regulates primordial follicle activation.

In general, primordial follicle activators are produced within the follicles or immediately associated tissue (McLaughlin \& McIver 2009). Hence, activationpromoting signals are expected to be largely autocrine (intrafollicular). Paracrine (extrafollicular) signals from adjacent primordial follicles may also have an effect, but extrafollicular signals are expected to be orders of magnitude weaker than intrafollicular autocrine signals due to loss of concentration with diffusion distance. The primordial follicle pool may collectively produce an extrafollicular signal that is correlated to the size of the ovarian reserve, but a mechanism by which primordial follicles can distinguish between a weak extrafollicular, and strong intrafollicular autocrine signal is not known to exist. In contrast, AMH is produced by developing follicles with little or no expression observed in primordial follicles (Bezard et al. 1987, Hirobe et al. 1994, Baarends et al. 1995, Gruijters et al. 2003, Weenen et al. 2004, Juengel \& McNatty 2005, Monniaux et al. 2012, Shahed \& Young 2013, Rocha et al. 2016). Signals such as AMH can correlate with the size of the developing follicle pool and can also act as a surrogate signal for the size of the primordial follicle pool, as these variables are highly correlated (Hansen et al. 2011). Furthermore, the AMH signal secreted from developing follicles does not have to compete with a local autocrine signal in primordial follicles. The pattern of AMH expression suggests that it inhibits primordial follicle activation in a manner that is correlated to the size of the ovarian reserve/developing follicle pool.

\section{AMH in the context of ovarian reserve at puberty}

A high variability in the initial ovarian reserve and the reserve size at puberty, between individuals, has been observed across multiple mammalian species, and the effect occurs in both genetically diverse and inbred populations

Published by Bioscientifica Ltd 
(Myers et al. 2004, Ireland et al. 2008, Depmann et al. 2015, Olcha et al. 2016). The efficacy of multiple processes, including primordial germ cell migration, oogonial proliferation, nurse-cell organelle transfer and oogonial incorporation into primordial follicles, all contribute to the initial primordial follicle count (Kerr et al. 2013, Lei \& Spradling 2016). Subsequent primordial follicle activation, programmed cell death and oocyte extrusion from the ovary are processes that further affect the size of the ovarian reserve at puberty (Wordinger et al. 1990, Tingen et al. 2009). Variability in ovarian reserve at the beginning of the reproductive phase of life is likely to be an unavoidable consequence of mammalian ovary development. It is possible that females with low ovarian reserve are simply at a reproductive disadvantage. An alternative possibility is that mechanisms have evolved to enable primordial follicles to be recruited at a rate that is optimal for a given ovarian reserve size.

The phenotype of the $\mathrm{AMH}^{-/-}$mouse might suggest that the role of $\mathrm{AMH}$ is to prevent the ovarian reserve from being depleted too quickly. A small initial ovarian reserve is postulated to correlate with an early onset of menopause (Faddy \& Gosden 1995, Wallace \& Kelsey 2010, Depmann et al. 2015). Shorter reproductive lifespans present fewer opportunities to produce offspring; hence, conserving the ovarian reserve until later in life has the potential to increase reproductive fitness. However, females born with low ovarian reserve are expected to have the lowest levels of AMH throughout life. Therefore, AMH does little to conserve ovarian reserve in these females. In contrast, females born with high ovarian reserve produce large amounts of AMH in early reproductive life, raising the question; why do females with the largest ovarian reserve have the strongest inhibition of primordial follicle activation? It is possible that conserving the ovarian reserve is only advantageous when the ovarian reserve is large. If this is the case, ovarian reserve-dependent modulation of primordial recruitment rates via $\mathrm{AMH}$ may be important for managing lifetime reproductive potential.

\section{AMH expression patterns are consistent with primordial follicle usage}

In women, the pool of remaining primordial follicles declines with age leading to progressive reductions in the absolute rate at which primordial follicles are lost from the ovary (Fig. 1B, Wallace \& Kelsey 2010, Depmann et al. 2015). The absolute rate of activation is a function of both the size of the remaining ovarian reserve and the proportion of the remaining reserve activated over a given period. The size of the ovarian reserve is determined by past events, but the relative rate of activation is a variable that can be modified by regulatory factors. When the rate of primordial follicle activation is considered as a proportion of the remaining follicle pool, an acceleration in the rate of decline is observed in the 4th and 5th decades of life (Fig. 1C, Faddy et al. 1992, Faddy \& Gosden 1995). Antral follicle counts also decline throughout life but at a slower rate than primordial follicles, and any age-related acceleration in the rate of decline is subtle, with some evidence suggesting that it remains constant (Rosen et al. 2010). Hence, relative increases in primordial follicle activation rates may enable the ageing ovaries to maintain larger antral follicle pools than would be possible otherwise.

The mechanism by which the ageing ovary increases primordial follicle recruitment rates has not been identified, but reduced inhibition of follicle activation is one possibility. Levels of the putative inhibitor oestradiol do not begin to decline until late in the perimenopausal period (Burger et al. 1995). However, circulating growth hormone and $\mathrm{AMH}$ levels decline progressively with age (Iranmanesh et al. 1991, Seifer et al. 2011, de Kat et al. 2016). Hippo signalling responds to changes in surrounding tissue elasticity (Hsueh et al. 2015), which may become altered with age-related fibrosis (Briley et al. 2016). Therefore, the age-related increase in primordial follicle activation may arise from a reduction in inhibitory signals rather than an increase in activation-promoting regulators. This is further supported by mutations in the $A M H$ and AMHR2 genes that are associated with primary ovarian insufficiency or decreased age at menopause (Kevenaar et al. 2007, Park et al. 2014, Alvaro Mercadal et al. 2015). Across the lifespan, increased rates of primordial follicle activation tend to coincide with lower levels of inhibitors of primordial follicle activation, including AMH.

\section{The effect of ovarian reserve on declining fertility}

The cessation of ovulatory cycles at menopause is sometimes considered to be the absolute end of the reproductive lifespan in women. However, the age at last child-birth occurs approximately 10 years earlier, which signifies the end of fertility in a functional and evolutionary sense (te Velde \& Pearson 2002, Eijkemans et al. 2014).

Published by Bioscientifica Ltd. 
The onset of infertility appears to occur gradually, as the time-to-pregnancy for couples attempting to conceive naturally increases with age (Gnoth et al. 2003). Oocyte quality appears to be a key factor in age-related infertility, as IVF embryo implantation rates are higher in older women when using oocytes from young donors, rather than their own (Tarin et al. 2014).

A combination of oocyte quality and developing oocyte quantity are likely determinants of female fertility (Faddy et al. 1992, te Velde \& Pearson 2002). The amount of time that oocytes spend suspended in meiosis-I has been proposed to lead to an accumulation of degenerative defects that could explain age-related infertility. Oocyte aneuploidy frequently arises at the resumption of meiosis-I and is embryonically lethal in most cases (Munne et al. 2004). Aneuploidy incidence rates increase with age in humans and mice, with evidence suggesting age-related degradation of cohesin proteins in the oocyte nucleus is involved (Chiang et al. 2010, Lister et al. 2010, Kuliev et al. 2011, Duncan et al. 2012). Oocyte mitochondrial counts also decline in older females, leading to reduced embryo viability (Wai et al. 2010, Kushnir et al. 2012, Fragouli et al. 2015). Additional factors that contribute to the age-related decline in oocyte quality may yet be discovered, but there is no current evidence to suggest that AMH directly affects oocyte quality. In assisted reproduction, AMH levels are predictive of oocyte yield but not the probability of achieving pregnancy (Fraisse et al. 2008, Broer et al. 2009, Hamilton et al. 2016). However, this does not exclude the possibility that AMH indirectly affects fertility by altering primordial follicle activation rates.

The limited oocyte pool hypothesis postulates that a declining ovarian reserve will lead to higher rates of aneuploidy due to a smaller antral follicle pool (Warburton 1989). In the absence of a suitable follicle, it was proposed that an over- or under-matured follicle with a higher propensity to release an aneuploid oocyte would be selected for ovulation (Warburton 1989). In mice, artificially reducing the ovarian reserve by unilateral ovariectomy causes reduced embryo viability in late reproductive life when compared to age-matched females (Biggers et al. 1962, Brook et al. 1984). Similarly, a low antral follicle count is associated with reduced pregnancy rates in cows (Mossa et al. 2012, Martinez et al. 2016). In humans, multiple studies suggest that increased rates of aneuploidy (Kline et al. 2000, Haadsma et al. 2010, KatzJaffe et al. 2013, Grande et al. 2015) or an inability to achieve pregnancy (Scott et al. 1995, El-Toukhy et al. 2002, Rosen et al. 2011) is associated with low ovarian reserve. Other studies have produced contradictory findings detecting no association between markers of reduced ovarian reserve and aneuploidy rates (Massie et al. 2008, Kline et al. 2011, Grande et al. 2014) or pregnancy rates (van Rooij et al. 2003). This has raised questions about the validity of the limited oocyte pool hypothesis, but human studies often involve women seeking fertility treatment, many of whom would have been considered infertile prior to the advent of assisted reproduction technologies. In the absence of accurate methods to assess fertility and primordial follicle numbers longitudinally, the question remains; what size of ovarian reserve is too small to maintain fertility and does this affect the age at which infertility occurs?

\section{The age-related decline in fertility and the limited oocyte pool effect}

The characteristics that determine which follicle is selected to be the dominant or preovulatory follicle are unclear. Presumably, selection is based on a measure of oocyte quality. There is evidence to support this, as oocytes secrete signals to granulosa and theca cells that promote follicle survival (Gilchrist et al. 2008). However, in the absence of a high-quality follicle, the hypothalamicpituitary-gonadal axis appears to select any available follicle. For example, the human historical data suggest that the ovary continues to ovulate for many years after the age of infertility onset (Eijkemans et al. 2014). In cows and horses, an ablated dominant follicle can be replaced by a subordinate follicle that would otherwise undergo atresia (Evans et al. 2002, Ginther et al. 2002a,b).

A simplified model of follicle selection in a polyovulatory species outlines one scenario where a large developing follicle pool is beneficial (Fig. 2). Reducing the size of the developing follicle pool can lead to the selection of a greater number of low-quality (nonviable) oocytes in this system. Age-related increases in the proportion of nonviable oocytes combined with age-related reductions in antral follicle counts exacerbate the problem. Hence, a limited oocyte-pool-like hypothesis is compatible with age-related reductions in oocyte quality, as the two processes are not necessarily mutually exclusive. In theory, this model is not restricted to aneuploidy and could apply to any form of reduced oocyte quality.

A single preovulatory follicle is selected per cycle in humans. The proposed model (Fig. 2) might imply that noticeable effects on oocyte quality in monovulatory species are only observed when the antral follicle count becomes very small (refer to Fig. 2). However, several aspects

Published by Bioscientifica Ltd. 
A Large pool, $50 \%$ viable
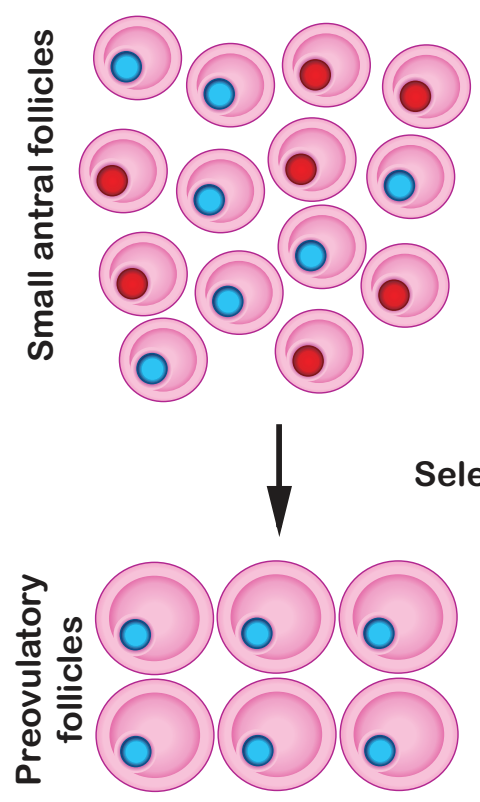

$100 \%$ viable
B Reduced pool, $50 \%$ viable
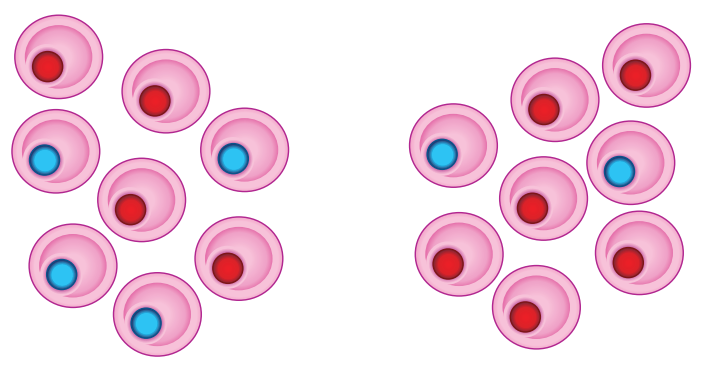

\section{Reduced pool,} $25 \%$ viable

Figure 2

A simplified model of quality-based follicle selection in a polyovulatory species. The model assumes that the hypothalamic-pituitary-gonadal axis selects 6 follicles per cycle for ovulation with a preference for viable/high-quality oocytes (blue) over non-viable/low-quality oocytes (red). The model also assumes that there will always be a proportion of oocytes that are inherently low quality or non-viable. When the pool of developing small antral follicles is large (A), there is capacity to choose a high-quality cohort of preovulatory follicles. When the pool of developing small antral follicles is reduced (B), there are fewer high-quality follicles to choose from and the proportion of high-quality preovulatory follicles decreases. When the size and quality of the small antral follicle pool is reduced (C), there is a greater reduction in preovulatory follicle quality. Note that this model has limitations, as it has not been confirmed that high-quality follicles are always selected, and the process is likely to contain an element of error. Similarly, the quality of oocytes in developing follicles has not been described in detail due to a lack of suitable methods. It is worth noting that additional oocyte defects may arise during the final stages of follicle maturation, but this is also proposed to be exacerbated in a limited oocyte pool scenario (Warburton 1989).

of ovarian biology constrain the functional size of the ovarian reserve during reproductive ageing. A substantial proportion of women have low antral follicle counts at the age of 35 years (Scheffer et al. 1999, Fanchin et al. 2003, Rosen et al. 2010). Furthermore, dominant follicle selection occurs over a short time window (a few days in humans) (Schipper et al. 1998, Baerwald et al. 2012). Only a proportion of the antral follicles are at a suitable stage for selection during the selection window, particularly in older women (Scheffer et al. 1999, Baerwald et al. 2003a,b, Bentzen et al. 2013). Hence, it is feasible that a limited oocyte-pool-like effect occurs at an earlier phase of the age-related fertility decline than originally proposed. In this circumstance, it is feasible that reducing negative regulators such as AMH could promote the formation of larger developing follicle pools and delay the onset of reproductive senescence.

The functions of $\mathrm{AMH}$ are conserved across the mammalian taxa but regulating the size of the developing follicle pool may be more important for certain species. For example, ageing mice maintain a similarly-sized large antral follicle pool to young mice but the older mice recruit from smaller primary follicle pools and have higher rates of aneuploidy (Fu et al. 2014). Ovarian reserve, determined by AMH levels, is correlated with litter size in dogs (Hollinshead et al. 2016), which could have large consequences for cumulative, lifetime reproductive fitness. In some strains of mice and cows, low ovarian reserve or reproductive ageing is associated with reduced corpus luteum function (Harman \& Talbert 1970, JimenezKrassel et al. 2009). In these cases, the mechanism of infertility may relate to a reduced ability to maintain pregnancy (Mossa et al. 2012, Martinez et al. 2016), rather than production of low-quality oocytes. Hence, it is possible that multiple selection pressures have preserved systems that generate a comparatively large developing follicle pool when ovarian reserve is low. 


\section{A potential biological role for AMH}

The largest changes in extrafollicular AMH levels occur across the female lifespan, suggesting that it regulates long-term processes. Any AMH-mediated inhibition of primordial follicle activation can be expected to be strongest early in the reproductive phase of life, with decreasing effects as age advances. In the context of a limited oocyte pool-like hypothesis where oocyte quality and quantity are important factors for fertility, AMH may help generate a developing follicle pool that is optimal for a given ovarian reserve (Fig. 3). Three possible biological functions for AMH can be hypothesised:

Hypothesis 1: Declining AMH in late reproductive life stimulates an increase in the relative rate of primordial follicle activation. Increased activation rates result in faster ovarian reserve depletion but may enable the developing follicle pool to remain large enough to support fertility for longer. In polyovulatory species, the effect may enable females to maintain large litters for longer. Small litters represent a reduced reproductive output relative to other females but carry ongoing opportunity costs as lactational

\section{Ovarian reserve}

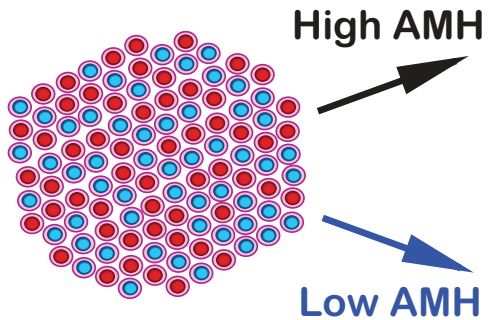

Small antral follicles

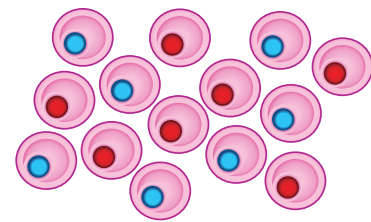

\section{Preovulatory follicles}
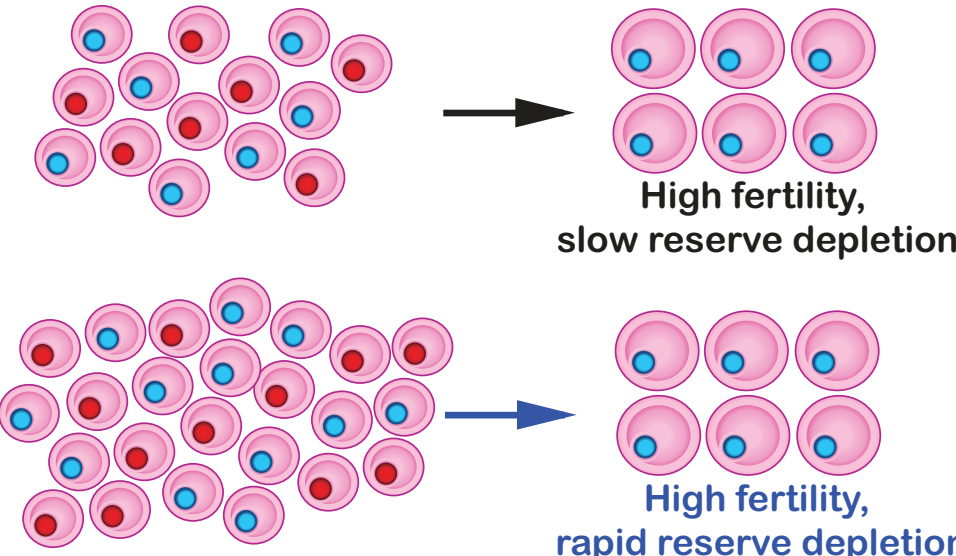

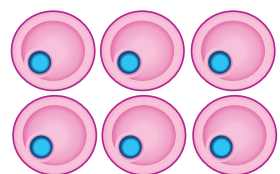

High fertility, rapid reserve depletion

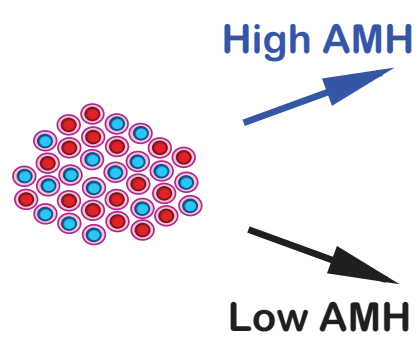

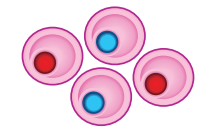

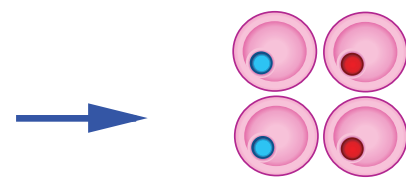

Low fertility, slow reserve depletion

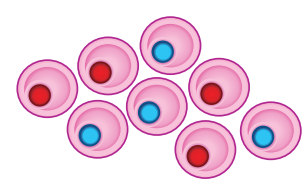

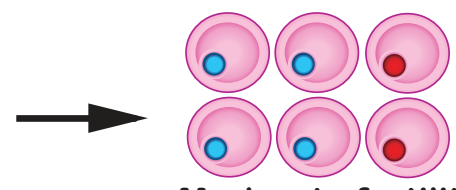

Moderate fertility, rapid reserve depletion

\section{Figure 3}

The putative effects variation in AMH levels when ovarian reserve is large or small in a polyovulatory species model. The pathways coloured black (upper and lower pathways) represent the observed levels of AMH when the ovarian reserve is large or small. The pathways coloured blue (middle pathways) are not observed in normal females but are included for the purpose of demonstration and comparison. Viable/high-quality follicles have oocytes coloured blue and non-viable/low-quality follicles have oocytes coloured red. When the ovarian reserve is large, the small antral follicle pool will be large regardless of AMH levels. However, the small antral follicle pool may be larger than necessary if AMH levels are low with a large ovarian reserve, leading to rapid depletion of the ovarian reserve without additional benefit to fertility. In females with low ovarian reserve, the low AMH levels will increase the relative rate of primordial follicle recruitment leading to a larger small antral follicle pool. This represents a trade-off between rapid ovarian reserve depletion for a moderate increase in fertility. If high AMH levels are present when the ovarian reserve is low, the expected reduction in the size of the small antral follicle pool has the potential to further reduce fertility. The proposed role of AMH is to enable a female to make the most of the ovarian reserve she was endowed with at the beginning of puberty. 
infertility delays further attempts to reproduce. In seasonal breeders, reproductive success requires pregnancy to occur over a short period of time and a small number of ovarian cycles. Extending the age of reproductive senescence by mere months could be sufficient to enable one additional breeding season. These effects could be particularly important for reproductive success in short-lived species.

Hypothesis 2: Females with a small ovarian reserve at puberty have low levels of $A M H$ and proportionately high primordial follicle activation rates over their lifespan. The absolute rate of primordial follicle activation is still expected to be low, but the reduced levels of AMH may mitigate the effect of low ovarian reserve and allow these females to maintain a relatively large developing follicle pool. The expected cost of this strategy is a reduced reproductive lifespan, but the expected benefit is a lower risk of having a developing follicle pool that is too small to support fertility.

Hypothesis 3: Females with a large ovarian reserve at puberty have high levels of AMH and proportionately low primordial follicle activation rates in the early phase of the reproductive lifespan. Past a certain size, larger developing follicle pools may produce diminishing returns on fertility. In this circumstance, females with large ovarian reserve can afford to inhibit primordial follicle activation to extend their reproductive lifespan while still producing a large developing follicle pool that is sufficient to sustain high fertility.

\section{Concluding statements}

A fixed rate of primordial follicle activation within a species is unlikely to be optimal for all females. The hypothesis put forward in this review is that AMH alters the relative rate of primordial follicle activation in a contextdependent manner to maximise lifetime reproductive opportunity. Such a system may be necessary to make adjustments for the inherent variability in ovarian reserve that is present when mammalian females reach puberty. The rate of the decline in primordial numbers has been described at the population level with cross-sectional data, but little information is available on rates of decline within individuals. Hence, the development of methods to quantify the ovarian reserve longitudinally will be essential for elucidating the functions of $\mathrm{AMH}$ and testing the hypotheses proposed herein. Furthermore, the control of primordial follicle activation is likely to be complex; hence, this putative function of AMH is likely to be part of a larger system with multiple, interacting regulators.

\begin{abstract}
Declaration of interest
The authors declare that there is no conflict of interest that could be perceived as prejudicing the impartiality of this review.
\end{abstract}

\section{Funding}

This work was supported by the Health Research Council of New Zealand (grant number 14-441).

\section{Acknowledgements}

The author gives thanks to Dr J L Juengel and Prof I S McLennan for their appraisal of the manuscript draft.

\section{References}

Adhikari D \& Liu K 2009 Molecular mechanisms underlying the activation of mammalian primordial follicles. Endocrine Reviews $\mathbf{3 0}$ 438-464. (doi:10.1210/er.2008-0048)

Alvaro Mercadal B, Imbert R, Demeestere I, Gervy C, De Leener A, Englert Y, Costagliola S \& Delbaere A 2015 AMH mutations with reduced in vitro bioactivity are related to premature ovarian insufficiency. Human Reproduction 30 1196-1202. (doi:10.1093/humrep/dev042)

Baarends WM, Uilenbroek JT, Kramer P, Hoogerbrugge JW, van Leeuwen EC, Themmen AP \& Grootegoed JA 1995 Antimüllerian hormone and anti-müllerian hormone type II receptor messenger ribonucleic acid expression in rat ovaries during postnatal development, the estrous cycle, and gonadotropin-induced follicle growth. Endocrinology 136 4951-4962. (doi:10.1210/en.136.11.4951)

Baerwald AR, Adams GP \& Pierson RA 2003a Characterization of ovarian follicular wave dynamics in women. Biology of Reproduction 69 1023-1031. (doi:10.1095/biolreprod.103.017772)

Baerwald AR, Adams GP \& Pierson RA 2003b A new model for ovarian follicular development during the human menstrual cycle. Fertility and Sterility 80 116-122. (doi:10.1016/S0015-0282(03)00544-2)

Baerwald AR, Adams GP \& Pierson RA 2012 Ovarian antral folliculogenesis during the human menstrual cycle: a review. Human Reproduction Update 18 73-91. (doi:10.1093/humupd/dmr039)

Batista EO, Macedo GG, Sala RV, Ortolan MD, Sa Filho MF, Del Valle TA, Jesus EF, Lopes RN, Renno FP \& Baruselli PS 2014 Plasma antimullerian hormone as a predictor of ovarian antral follicular population in Bos indicus (Nelore) and Bos taurus (Holstein) heifers. Reproduction in Domestic Animals 49 448-452. (doi:10.1111/rda.12304)

Bentzen JG, Forman JL, Johannsen TH, Pinborg A, Larsen EC \& Andersen AN 2013 Ovarian antral follicle subclasses and anti-mullerian hormone during normal reproductive aging. Journal of Clinical Endocrinology and Metabolism 98 1602-1611. (doi:10.1210/jc.2012-1829)

Bezard J, Vigier B, Tran D, Mauleon P \& Josso N 1987 Immunocytochemical study of anti-Mullerian hormone in sheep ovarian follicles during fetal and post-natal development. Journal of Reproduction and Fertility 80 509-516. (doi:10.1530/jrf.0.0800509)

Biggers JD, Finn CA \& Mc LA 1962 Long-term reproductive performance of female mice. I. Effect of removing one ovary. Journal of Reproduction and Fertility 3 303-312. (doi:10.1530/jrf.0.0030303)

Brent LJ, Franks DW, Foster EA, Balcomb KC, Cant MA \& Croft DP 2015 Ecological knowledge, leadership, and the evolution of menopause in killer whales. Current Biology 25 746-750. (doi:10.1016/j. cub.2015.01.037)

Briley SM, Jasti S, McCracken JM, Hornick JE, Fegley B, Pritchard MT \& Duncan FE 2016 Reproductive age-associated fibrosis in the stroma of the mammalian ovary. Reproduction 152 245-260. (doi:10.1530/ REP-16-0129)
๑ 2017 Society for Endocrinology Printed in Great Britain 
Broekmans FJ, Soules MR \& Fauser BC 2009 Ovarian aging: mechanisms and clinical consequences. Endocrine Reviews 30 465-493. (doi:10.1210/er.2009-0006)

Broer SL, Mol BW, Hendriks D \& Broekmans FJ 2009 The role of antimullerian hormone in prediction of outcome after IVF: comparison with the antral follicle count. Fertility and Sterility 91 705-714. (doi:10.1016/j.fertnstert.2007.12.013)

Brook JD, Gosden RG \& Chandley AC 1984 Maternal ageing and aneuploid embryos - evidence from the mouse that biological and not chronological age is the important influence. Human Genetics $\mathbf{6 6}$ 41-45. (doi:10.1007/BF00275184)

Bungum L, Jacobsson AK, Rosen F, Becker C, Yding Andersen C, Guner N \& Giwercman A 2011 Circadian variation in concentration of antiMullerian hormone in regularly menstruating females: relation to age, gonadotrophin and sex steroid levels. Human Reproduction 26 678-684. (doi:10.1093/humrep/deq380)

Burger HG, Dudley EC, Hopper JL, Shelley JM, Green A, Smith A, Dennerstein L \& Morse C 1995 The endocrinology of the menopausal transition: a cross-sectional study of a population-based sample. Journal of Clinical Endocrinology and Metabolism 80 3537-3545. (doi:10.1210/jc.80.12.3537)

Campbell BK, Clinton M \& Webb R 2012 The role of anti-Mullerian hormone $(\mathrm{AMH})$ during follicle development in a monovulatory species (sheep). Endocrinology 153 4533-4543. (doi:10.1210/en.2012-1158)

Carlsson IB, Scott JE, Visser JA, Ritvos O, Themmen AP \& Hovatta O 2006 Anti-Mullerian hormone inhibits initiation of growth of human primordial ovarian follicles in vitro. Human Reproduction $\mathbf{2 1}$ 2223-2227. (doi:10.1093/humrep/del165)

Chiang T, Duncan FE, Schindler K, Schultz RM \& Lampson MA 2010 Evidence that weakened centromere cohesion is a leading cause of age-related aneuploidy in oocytes. Current Biology $201522-1528$. (doi:10.1016/j.cub.2010.06.069)

Chong YH, Campbell AJ, Farrand S \& McLennan IS 2012 Anti-Mullerian hormone level in older women: detection of granulosa cell tumor recurrence. International Journal of Gynecological Cancer 22 1497-1499. (doi:10.1097/IGC.0b013e318270ac69)

Cimino I, Casoni F, Liu X, Messina A, Parkash J, Jamin SP, CatteauJonard S, Collier F, Baroncini M, Dewailly D, et al. 2016 Novel role for anti-Mullerian hormone in the regulation of GnRH neuron excitability and hormone secretion. Nature Communications 710055. (doi:10.1038/ncomms10055)

Claes A, Ball BA, Scoggin KE, Esteller-Vico A, Kalmar JJ, Conley AJ, Squires EL \& Troedsson MH 2015 The interrelationship between antiMullerian hormone, ovarian follicular populations and age in mares. Equine Veterinary Journal 47 537-541. (doi:10.1111/evj.12328)

Clarke TR, Hoshiya Y, Yi SE, Liu X, Lyons KM \& Donahoe PK 2001 Mullerian inhibiting substance signaling uses a bone morphogenetic protein (BMP)-like pathway mediated by ALK2 and induces SMAD6 expression. Molecular Endocrinology 15 946-959. (doi:10.1210/me.15.6.946)

de Kat AC, van der Schouw YT, Eijkemans MJ, Herber-Gast GC, Visser JA, Verschuren WM \& Broekmans FJ 2016 Back to the basics of ovarian aging: a population-based study on longitudinal anti-Mullerian hormone decline. BMC Medicine 14 151. (doi:10.1186/s12916-016-0699-y)

de Vet A, Laven JS, de Jong FH, Themmen AP \& Fauser BC 2002 Antimullerian hormone serum levels: a putative marker for ovarian aging. Fertility and Sterility 77 357-362. (doi:10.1016/S0015-0282(01)02993-4)

Depmann M, Faddy MJ, van der Schouw YT, Peeters PH, Broer SL, Kelsey TW, Nelson SM \& Broekmans FJ 2015 The relationship between variation in size of the primordial follicle pool and age at natural menopause. Journal of Clinical Endocrinology and Metabolism 100 E845-E851. (doi:10.1210/jc.2015-1298)

Dole G, Nilsson EE \& Skinner MK 2008 Glial-derived neurotrophic factor promotes ovarian primordial follicle development and cellcell interactions during folliculogenesis. Reproduction 135 671-682. (doi:10.1530/REP-07-0405)

Duncan FE, Hornick JE, Lampson MA, Schultz RM, Shea LD \& Woodruff TK 2012 Chromosome cohesion decreases in human eggs with advanced maternal age. Aging Cell 11 1121-1124. (doi:10.1111/ j.1474-9726.2012.00866.x)

Durlinger AL, Kramer P, Karels B, de Jong FH, Uilenbroek JT, Grootegoed JA \& Themmen AP 1999 Control of primordial follicle recruitment by anti-Mullerian hormone in the mouse ovary. Endocrinology 140 5789-5796. (doi:10.1210/en.140.12.5789)

Durlinger AL, Gruijters MJ, Kramer P, Karels B, Ingraham HA, Nachtigal MW, Uilenbroek JT, Grootegoed JA \& Themmen AP 2002 Anti-Mullerian hormone inhibits initiation of primordial follicle growth in the mouse ovary. Endocrinology 143 1076-1084. (doi:10.1210/en.143.3.1076)

Eijkemans MJ, van Poppel F, Habbema DF, Smith KR, Leridon H \& te Velde ER 2014 Too old to have children? Lessons from natural fertility populations. Human Reproduction 29 1304-1312. (doi:10.1093/ humrep/deu056)

El-Toukhy T, Khalaf Y, Hart R, Taylor A \& Braude P 2002 Young age does not protect against the adverse effects of reduced ovarian reserve - an eight year study. Human Reproduction 17 1519-1524. (doi:10.1093/ humrep/17.6.1519)

Erbas O, Akman L, Yavasoglu A, Terek MC, Akman T \& Taskiran D 2014 Oxytocin improves follicular reserve in a cisplatin-induced gonadotoxicity model in rats. BioMed Research International 2014 703691. (doi:10.1155/2014/703691)

Evans AC, Flynn JD, Duffy P, Knight PG \& Boland MP 2002 Effects of ovarian follicle ablation on FSH, oestradiol and inhibin A concentrations and growth of other follicles in sheep. Reproduction 123 59-66. (doi:10.1530/rep.0.1230059)

Faddy MJ \& Gosden RG 1995 A mathematical model of follicle dynamics in the human ovary. Human Reproduction 10 770-775. (doi:10.1093/ oxfordjournals.humrep.a136036)

Faddy MJ, Gosden RG, Gougeon A, Richardson SJ \& Nelson JF 1992 Accelerated disappearance of ovarian follicles in mid-life: implications for forecasting menopause. Human Reproduction 7 1342-1346. (doi:10.1093/oxfordjournals.humrep.a137570)

Fanchin R, Schonauer LM, Righini C, Guibourdenche J, Frydman R \& Taieb J 2003 Serum anti-Mullerian hormone is more strongly related to ovarian follicular status than serum inhibin B, estradiol, FSH and LH on day 3. Human Reproduction 18 323-327. (doi:10.1093/humrep/deg042)

Feeney A, Nilsson E \& Skinner MK 2014 Cytokine (IL16) and tyrphostin actions on ovarian primordial follicle development. Reproduction 148 321-331. (doi:10.1530/REP-14-0246)

Fleming R, Kelsey TW, Anderson RA, Wallace WH \& Nelson SM 2012 Interpreting human follicular recruitment and antimullerian hormone concentrations throughout life. Fertility and Sterility 98 1097-1102. (doi:10.1016/j.fertnstert.2012.07.1114)

Fragouli E, Spath K, Alfarawati S, Kaper F, Craig A, Michel CE, Kokocinski F, Cohen J, Munne S \& Wells D 2015 Altered levels of mitochondrial DNA are associated with female age, aneuploidy, and provide an independent measure of embryonic implantation potential. PLoS Genetics 11 e1005241. (doi:10.1371/journal.pgen.1005241)

Fraisse T, Ibecheole V, Streuli I, Bischof P \& de Ziegler D 2008 Undetectable serum anti-Mullerian hormone levels and occurrence of ongoing pregnancy. Fertility and Sterility 89 723.e9-723.e11. (doi:10.1016/j.fertnstert.2007.03.084)

Fu X, Cheng J, Hou Y \& Zhu S 2014 The association between the oocyte pool and aneuploidy: a comparative study of the reproductive potential of young and aged mice. Journal of Assisted Reproduction and Genetics 31 323-331. (doi:10.1007/s10815-013-0160-5)

Gigli I, Cushman RA, Wahl CM \& Fortune JE 2005 Evidence for a role for anti-Mullerian hormone in the suppression of follicle activation in mouse ovaries and bovine ovarian cortex grafted beneath the chick chorioallantoic membrane. Molecular Reproduction and Development 71 480-488. (doi:10.1002/mrd.20338)

Gilchrist RB, Lane M \& Thompson JG 2008 Oocyte-secreted factors: regulators of cumulus cell function and oocyte quality. Human Reproduction Update 14 159-177. (doi:10.1093/humupd/dmm040)

Ginther OJ, Beg MA, Bergfelt DR \& Kot K 2002a Activin A, estradiol, and free insulin-like growth factor I in follicular fluid preceding the

Published by Bioscientifica Ltd 
experimental assumption of follicle dominance in cattle. Biology of Reproduction 67 14-19. (doi:10.1095/biolreprod67.1.14)

Ginther OJ, Meira C, Beg MA \& Bergfelt DR 2002b Follicle and endocrine dynamics during experimental follicle deviation in mares. Biology of Reproduction 67 862-867. (doi:10.1095/biolreprod.102.004309)

Gnoth C, Godehardt D, Godehardt E, Frank-Herrmann P \& Freundl G 2003 Time to pregnancy: results of the German prospective study and impact on the management of infertility. Human Reproduction 18 1959-1966. (doi:10.1093/humrep/deg366)

Gnoth C, Roos J, Broomhead D, Schiffner J, Godehardt E, Freundl G \& Johnson S 2015 Antimullerian hormone levels and numbers and sizes of antral follicles in regularly menstruating women of reproductive age referenced to true ovulation day. Fertility and Sterility $\mathbf{1 0 4}$ 1535-1543.e4. (doi:10.1016/j.fertnstert.2015.08.027)

Gouedard L, Chen YG, Thevenet L, Racine C, Borie S, Lamarre I, Josso N, Massague J \& di Clemente N 2000 Engagement of bone morphogenetic protein type IB receptor and Smad1 signaling by anti-Mullerian hormone and its type II receptor. Journal of Biological Chemistry 275 27973-27978. (doi:10.1074/jbc.m002704200)

Grande M, Borobio V, Jimenez JM, Bennasar M, Stergiotou I, Penarrubia J \& Borrell A 2014 Antral follicle count as a marker of ovarian biological age to reflect the background risk of fetal aneuploidy. Human Reproduction 29 1337-1343. (doi:10.1093/humrep/deu055)

Grande M, Borobio V, Bennasar M, Stergiotou I, Mercade I, Masoller N, Penarrubia J \& Borrell A 2015 Role of ovarian reserve markers, antimullerian hormone and antral follicle count, as aneuploidy markers in ongoing pregnancies and miscarriages. Fertility and Sterility 103 1221-1227.e2. (doi:10.1016/j.fertnstert.2015.02.022)

Griesinger G, Dafopoulos K, Buendgen N, Cascorbi I, Georgoulias P, Zavos A, Messini CI \& Messinis IE 2012 Elimination half-life of antiMullerian hormone. Journal of Clinical Endocrinology and Metabolism 97 2160-2163. (doi:10.1210/jc.2012-1070)

Groome NP, Illingworth PJ, O’Brien M, Pai R, Rodger FE, Mather JP \& McNeilly AS 1996 Measurement of dimeric inhibin B throughout the human menstrual cycle. Journal of Clinical Endocrinology and Metabolism 81 1401-1405. (doi:10.1210/jc.81.4.1401)

Gruijters MJ, Visser JA, Durlinger AL \& Themmen AP 2003 AntiMullerian hormone and its role in ovarian function. Molecular and Cellular Endocrinology 211 85-90. (doi:10.1016/j.mce.2003.09.024)

Haadsma ML, Mooij TM, Groen H, Burger CW, Lambalk CB, Broekmans FJ, van Leeuwen FE, Bouman K, Hoek A \& Group OP 2010 A reduced size of the ovarian follicle pool is associated with an increased risk of a trisomic pregnancy in IVF-treated women. Human Reproduction $\mathbf{2 5}$ 552-558. (doi:10.1093/humrep/dep404)

Hadlow N, Brown SJ, Habib A, Wardrop R, Joseph J, Gillett M, Maguire R \& Conradie $\mathrm{J} 2016$ Quantifying the intraindividual variation of antimullerian hormone in the ovarian cycle. Fertility and Sterility $\mathbf{1 0 6}$ 1230-1237. (doi:10.1016/j.fertnstert.2016.06.009)

Hagen CP, Aksglaede L, Sorensen K, Main KM, Boas M, Cleemann L, Holm K, Gravholt CH, Andersson AM, Pedersen AT, et al. 2010 Serum levels of anti-Mullerian hormone as a marker of ovarian function in 926 healthy females from birth to adulthood and in 172 Turner syndrome patients. Journal of Clinical Endocrinology and Metabolism 95 5003-5010. (doi:10.1210/jc.2010-0930)

Hamilton K, Hadlow N, Roberts P, Sykes P, McClements A, Coombes $\mathrm{J} \&$ Matson P 2016 Longitudinal changes in maternal serum concentrations of antimullerian hormone in individual women during conception cycles and early pregnancy. Fertility and Sterility 106 1407-1413.e2. (doi:10.1016/j.fertnstert.2016.07.1113)

Hansen KR, Hodnett GM, Knowlton N \& Craig LB 2011 Correlation of ovarian reserve tests with histologically determined primordial follicle number. Fertility and Sterility 95 170-175. (doi:10.1016/j. fertnstert.2010.04.006)

Harman SM \& Talbert GB 1970 The effect of maternal age on ovulation, corpora lutea of pregnancy, and implantation failure in mice. Journal of Reproduction and Fertility 23 33-39. (doi:10.1530/jrf.0.0230033)
Hayes E, Kushnir V, Ma X, Biswas A, Prizant H, Gleicher N \& Sen A 2016 Intra-cellular mechanism of Anti-Mullerian hormone (AMH) in regulation of follicular development. Molecular and Cellular Endocrinology 433 56-65. (doi:10.1016/j.mce.2016.05.019)

Hirobe S, He WW, Gustafson ML, MacLaughlin DT \& Donahoe PK 1994 Mullerian inhibiting substance gene expression in the cycling rat ovary correlates with recruited or graafian follicle selection. Biology of Reproduction 50 1238-1243. (doi:10.1095/biolreprod50.6.1238)

Hollinshead FK, Walker C \& Hanlon DW 2016 Determination of the normal reference interval for anti-Mullerian hormone (AMH) in bitches and use of $\mathrm{AMH}$ as a potential predictor of litter size. Reproduction in Domestic Animals [in press]. (doi:10.1111/rda.12822)

Hsueh AJ, Kawamura K, Cheng Y \& Fauser BC 2015 Intraovarian control of early folliculogenesis. Endocrine Reviews 36 1-24. (doi:10.1210/ er.2014-1020)

Iranmanesh A, Lizarralde G \& Veldhuis JD 1991 Age and relative adiposity are specific negative determinants of the frequency and amplitude of growth hormone (GH) secretory bursts and the half-life of endogenous GH in healthy men. Journal of Clinical Endocrinology and Metabolism 73 1081-1088. (doi:10.1210/jcem-73-5-1081)

Ireland JL, Scheetz D, Jimenez-Krassel F, Themmen AP, Ward F, Lonergan P, Smith GW, Perez GI, Evans AC \& Ireland JJ 2008 Antral follicle count reliably predicts number of morphologically healthy oocytes and follicles in ovaries of young adult cattle. Biology of Reproduction 79 1219-1225. (doi:10.1095/biolreprod.108.071670)

Jeppesen JV, Anderson RA, Kelsey TW, Christiansen SL, Kristensen SG, Jayaprakasan K, Raine-Fenning N, Campbell BK \& Yding Andersen C 2013 Which follicles make the most anti-Mullerian hormone in humans? Evidence for an abrupt decline in AMH production at the time of follicle selection. Molecular Human Reproduction 19 519-527. (doi:10.1093/molehr/gat024)

Jimenez-Krassel F, Folger JK, Ireland JL, Smith GW, Hou X, Davis JS, Lonergan P, Evans AC \& Ireland JJ 2009 Evidence that high variation in ovarian reserves of healthy young adults has a negative impact on the corpus luteum and endometrium during estrous cycles in cattle. Biology of Reproduction 80 1272-1281. (doi:10.1095/ biolreprod.108.075093)

Jones KT \& Lane SI 2013 Molecular causes of aneuploidy in mammalian eggs. Development 140 3719-3730. (doi:10.1242/dev.090589)

Juengel JL \& McNatty KP 2005 The role of proteins of the transforming growth factor-beta superfamily in the intraovarian regulation of follicular development. Human Reproduction Update 11 143-160. (doi:10.1093/humupd/dmh061)

Juengel JL, Whale LJ, Wylde KA, Greenwood P, McNatty KP \& Eckery DC 2002 Expression of anti-Mullerian hormone mRNA during gonadal and follicular development in the brushtail possum (Trichosurus vulpecula). Reproduction Fertility and Development 14 345-353. (doi:10.1071/RD02027)

Katz-Jaffe MG, Surrey ES, Minjarez DA, Gustofson RL, Stevens JM \& Schoolcraft WB 2013 Association of abnormal ovarian reserve parameters with a higher incidence of aneuploid blastocysts. Obstetrics and Gynecology 121 71-77. (doi:10.1097/ AOG.0b013e318278eeda)

Kelsey TW, Wright P, Nelson SM, Anderson RA \& Wallace WH 2011 A validated model of serum anti-mullerian hormone from conception to menopause. PLOS ONE 6 e22024. (doi:10.1371/journal. pone.0022024)

Kerr JB, Myers M \& Anderson RA 2013 The dynamics of the primordial follicle reserve. Reproduction 146 R205-R215. (doi:10.1530/REP-13-0181)

Kevenaar ME, Meerasahib MF, Kramer P, van de Lang-Born BM, de Jong FH, Groome NP, Themmen AP \& Visser JA 2006 Serum anti-mullerian hormone levels reflect the size of the primordial follicle pool in mice. Endocrinology 147 3228-3234. (doi:10.1210/en.2005-1588)

Kevenaar ME, Themmen AP, Rivadeneira F, Uitterlinden AG, Laven JS, van Schoor NM, Lips P, Pols HA \& Visser JA 2007 A polymorphism in the AMH type II receptor gene is associated with age at menopause http://joe.endocrinology-journals.org

DOI: $10.1530 / J O E-16-0522$
C) 2017 Society for Endocrinology Printed in Great Britain 
in interaction with parity. Human Reproduction 22 2382-2388. (doi:10.1093/humrep/dem176)

Kissell KA, Danaher MR, Schisterman EF, Wactawski-Wende J, Ahrens KA, Schliep K, Perkins NJ, Sjaarda L, Weck J \& Mumford SL 2014 Biological variability in serum anti-Mullerian hormone throughout the menstrual cycle in ovulatory and sporadic anovulatory cycles in eumenorrheic women. Human Reproduction 29 1764-1772. (doi:10.1093/humrep/deu142)

Kline J, Kinney A, Levin B \& Warburton D 2000 Trisomic pregnancy and earlier age at menopause. American Journal of Human Genetics 67 395-404. (doi:10.1086/303009)

Kline JK, Kinney AM, Levin B, Kelly AC, Ferin M \& Warburton D 2011 Trisomic pregnancy and elevated FSH: implications for the oocyte pool hypothesis. Human Reproduction 26 1537-1550. (doi:10.1093/humrep/der091)

Kristensen SG, Andersen K, Clement CA, Franks S, Hardy K \& Andersen CY 2013 Expression of TGF-beta superfamily growth factors, their receptors, the associated SMADs and antagonists in five isolated size-matched populations of pre-antral follicles from normal human ovaries. Molecular Human Reproduction 20 293-308. (doi:10.1093/molehr/gat089)

Kuliev A, Zlatopolsky Z, Kirillova I, Spivakova J \& Cieslak Janzen J 2011 Meiosis errors in over 20,000 oocytes studied in the practice of preimplantation aneuploidy testing. Reproductive BioMedicine Online 22 2-8. (doi:10.1016/j.rbmo.2010.08.014)

Kushnir VA, Ludaway T, Russ RB, Fields EJ, Koczor C \& Lewis W 2012 Reproductive aging is associated with decreased mitochondrial abundance and altered structure in murine oocytes. Journal of Assisted Reproduction and Genetics 29 637-642. (doi:10.1007/s10815-012-9771-5)

La Marca A, Grisendi V \& Griesinger G 2013 How much does AMH really vary in normal women? International Journal of Endocrinology 2013 959487. (doi:10.1155/2013/959487)

Lambert-Messerlian G, Plante B, Eklund EE, Raker C \& Moore RG 2016 Levels of antimullerian hormone in serum during the normal menstrual cycle. Fertility and Sterility 105 208-213.e1. (doi:10.1016/j. fertnstert.2015.09.033)

Lei L \& Spradling AC 2016 Mouse oocytes differentiate through organelle enrichment from sister cyst germ cells. Science 352 95-99. (doi:10.1126/science.aad2156)

Lister LM, Kouznetsova A, Hyslop LA, Kalleas D, Pace SL, Barel JC, Nathan A, Floros V, Adelfalk C, Watanabe Y, et al. 2010 Age-related meiotic segregation errors in mammalian oocytes are preceded by depletion of cohesin and Sgo2. Current Biology 20 1511-1521. (doi:10.1016/j.cub.2010.08.023)

Marsh H \& Kasuya T 1986 Evidence for reproductive senescence in female cetaceans. Report of the International Whaling Commission 8 5-7.

Martinez MF, Sanderson N, Quirke LD, Lawrence SB \& Juengel JL 2016 Association between antral follicle count and reproductive measures in New Zealand lactating dairy cows maintained in a pasture-based production system. Theriogenology 85 466-475. (doi:10.1016/j. theriogenology.2015.09.026)

Massie JA, Burney RO, Milki AA, Westphal LM \& Lathi RB 2008 Basal follicle-stimulating hormone as a predictor of fetal aneuploidy. Fertility and Sterility 90 2351-2355. (doi:10.1016/j. fertnstert.2007.10.041)

McGee EA \& Hsueh AJ 2000 Initial and cyclic recruitment of ovarian follicles. Endocrine Reviews 21 200-214. (doi:10.1210/er.21.2.200)

McLaughlin EA \& McIver SC 2009 Awakening the oocyte: controlling primordial follicle development. Reproduction 137 1-11. (doi:10.1530/ REP-08-0118)

Merhi Z, Buyuk E, Berger DS, Zapantis A, Israel DD, Chua S Jr \& Jindal S 2013 Leptin suppresses anti-Mullerian hormone gene expression through the JAK2/STAT3 pathway in luteinized granulosa cells of women undergoing IVF. Human Reproduction 28 1661-1669. (doi:10.1093/humrep/det072)

Mishina Y, Rey R, Finegold MJ, Matzuk MM, Josso N, Cate RL \& Behringer RR 1996 Genetic analysis of the Mullerian-inhibiting substance signal transduction pathway in mammalian sexual differentiation. Genes and Development 10 2577-2587. (doi:10.1101/gad.10.20.2577)

Modi D, Bhartiya D \& Puri C 2006 Developmental expression and cellular distribution of Mullerian inhibiting substance in the primate ovary. Reproduction 132 443-453. (doi:10.1530/rep.1.01178)

Monniaux D, Drouilhet L, Rico C, Estienne A, Jarrier P, Touze JL, Sapa J, Phocas F, Dupont J, Dalbies-Tran R, et al. 2012 Regulation of antiMullerian hormone production in domestic animals. Reproduction Fertility and Development 25 1-16. (doi:10.1071/RD12270)

Monniaux D, Clement F, Dalbies-Tran R, Estienne A, Fabre S, Mansanet C \& Monget P 2014 The ovarian reserve of primordial follicles and the dynamic reserve of antral growing follicles: what is the link? Biology of Reproduction 90 85. (doi:10.1095/biolreprod.113.117077)

Mossa F, Walsh SW, Butler ST, Berry DP, Carter F, Lonergan P, Smith GW, Ireland JJ \& Evans AC 2012 Low numbers of ovarian follicles $>/=3$ $\mathrm{mm}$ in diameter are associated with low fertility in dairy cows. Journal of Dairy Science 95 2355-2361. (doi:10.3168/jds.2011-4325)

Munne S, Bahce M, Sandalinas M, Escudero T, Marquez C, Velilla E, Colls P, Oter M, Alikani M \& Cohen J 2004 Differences in chromosome susceptibility to aneuploidy and survival to first trimester. Reproductive BioMedicine Online 8 81-90. (doi:10.1016/S1472-6483(10)60501-9)

Myers M, Britt KL, Wreford NG, Ebling FJ \& Kerr JB 2004 Methods for quantifying follicular numbers within the mouse ovary. Reproduction 127 569-580. (doi:10.1530/rep.1.00095)

Nilsson E, Rogers N \& Skinner MK 2007 Actions of anti-Mullerian hormone on the ovarian transcriptome to inhibit primordial to primary follicle transition. Reproduction 134 209-221. (doi:10.1530/ REP-07-0119)

Nilsson E, Dole G \& Skinner MK 2009 Neurotrophin NT3 promotes ovarian primordial to primary follicle transition. Reproduction 138 697-707. (doi:10.1530/REP-09-0179)

Nilsson EE, Schindler R, Savenkova MI \& Skinner MK 2011 Inhibitory actions of Anti-Mullerian Hormone (AMH) on ovarian primordial follicle assembly. PLOS ONE 6 e20087. (doi:10.1371/journal. pone.0020087)

Nilsson EE, Larsen G \& Skinner MK 2014 Roles of Gremlin 1 and Gremlin 2 in regulating ovarian primordial to primary follicle transition. Reproduction 147 865-874. (doi:10.1530/REP-14-0005)

Novembri R, Funghi L, Voltolini C, Belmonte G, Vannuccini S, Torricelli M \& Petraglia F 2015 Placenta expresses anti-Mullerian hormone and its receptor: Sex-related difference in fetal membranes. Placenta 36 731-737. (doi:10.1016/j.placenta.2015.04.009)

Nussey DH, Froy H, Lemaitre JF, Gaillard JM \& Austad SN 2013 Senescence in natural populations of animals: widespread evidence and its implications for bio-gerontology. Ageing Research Reviews 12 214-225. (doi:10.1016/j.arr.2012.07.004)

Olcha M, Franasiak JM, Shastri S, Molinaro TA, Congdon H, Treff NR $\&$ Scott RT Jr 2016 Genotypically determined ancestry across an infertile population: ovarian reserve and response parameters are not influenced by continental origin. Fertility and Sterility 106 475-480. (doi:10.1016/j.fertnstert.2016.03.052)

Orvis GD, Jamin SP, Kwan KM, Mishina Y, Kaartinen VM, Huang S, Roberts AB, Umans L, Huylebroeck D, Zwijsen A, et al. 2008 Functional redundancy of TGF-beta family type I receptors and receptor-Smads in mediating anti-Mullerian hormone-induced Mullerian duct regression in the mouse. Biology of Reproduction $\mathbf{7 8}$ 994-1001. (doi:10.1095/biolreprod.107.066605)

Packer C, Tatar M \& Collins A 1998 Reproductive cessation in female mammals. Nature 392 807-811. (doi:10.1038/33910)

Pankhurst MW \& Chong YH 2016 Variation in circulating antimullerian hormone precursor during the periovulatory and acute postovulatory phases of the human ovarian cycle. Fertility and Sterility 1061238 1243.e2. (doi:10.1016/j.fertnstert.2016.06.010)

Park M, Suh DS, Lee K \& Bae J 2014 Positive cross talk between FOXL2 and antimullerian hormone regulates ovarian reserve. Fertility and Sterility 102 847-855.e1. (doi:10.1016/j.fertnstert.2014.05.031) 
Rice S, Ojha K, Whitehead S \& Mason H 2007 Stage-specific expression of androgen receptor, follicle-stimulating hormone receptor, and anti-Mullerian hormone type II receptor in single, isolated, human preantral follicles: relevance to polycystic ovaries. Journal of Clinical Endocrinology and Metabolism 92 1034-1040. (doi:10.1210/jc.20061697)

Richardson BE \& Lehmann R 2010 Mechanisms guiding primordial germ cell migration: strategies from different organisms. Nature Reviews Molecular Cell Biology 11 37-49. (doi:10.1038/nrm2815)

Rocha R, Lima LF, Carvalho AA, Chaves RN, Bernuci MP, Rosa ESA, Rodrigues A, Campello CC \& Figueiredo JR 2016 Immunolocalization of the anti-mullerian hormone (AMH) in caprine follicles and the effects of $\mathrm{AMH}$ on in vitro culture of caprine pre-antral follicles enclosed in ovarian tissue. Reproduction in Domestic Animals $\mathbf{5 1}$ 212-219. (doi:10.1111/rda.12668)

Rosen MP, Sternfeld B, Schuh-Huerta SM, Reijo Pera RA, McCulloch CE \& Cedars MI 2010 Antral follicle count: absence of significant midlife decline. Fertility and Sterility 94 2182-2185. (doi:10.1016/j. fertnstert.2009.12.045)

Rosen MP, Johnstone E, Addauan-Andersen C \& Cedars MI 2011 A lower antral follicle count is associated with infertility. Fertility and Sterility 95 1950-1954.e1. (doi:10.1016/j.fertnstert.2011.01.151)

Scheffer GJ, Broekmans FJ, Dorland M, Habbema JD, Looman CW \& te Velde ER 1999 Antral follicle counts by transvaginal ultrasonography are related to age in women with proven natural fertility. Fertility and Sterility 72 845-851. (doi:10.1016/S0015-0282(99)00396-9)

Schipper I, Hop WC \& Fauser BC 1998 The follicle-stimulating hormone (FSH) threshold/window concept examined by different interventions with exogenous FSH during the follicular phase of the normal menstrual cycle: duration, rather than magnitude, of FSH increase affects follicle development. Journal of Clinical Endocrinology and Metabolism 83 1292-1298. (doi:10.1210/jc.83.4.1292)

Schmidt KL, Kryger-Baggesen N, Byskov AG \& Andersen CY 2005 AntiMullerian hormone initiates growth of human primordial follicles in vitro. Molecular and Cellular Endocrinology 234 87-93. (doi:10.1016/j. mce.2004.12.010)

Scott RT, Opsahl MS, Leonardi MR, Neall GS, Illions EH \& Navot D 1995 Life table analysis of pregnancy rates in a general infertility population relative to ovarian reserve and patient age. Human Reproduction 10 1706-1710. (doi:10.1093/oxfordjournals.humrep. a136159)

Sedes L, Leclerc A, Moindjie H, Cate RL, Picard JY, di Clemente N \& Jamin SP 2013 Anti-Mullerian hormone recruits BMPR-IA in immature granulosa cells. PLOS ONE 8 e81551. (doi:10.1371/journal. pone.0081551)

Seifer DB, Baker VL \& Leader B 2011 Age-specific serum anti-Mullerian hormone values for 17,120 women presenting to fertility centers within the United States. Fertility and Sterility 95 747-750. (doi:10.1016/j.fertnstert.2010.10.011)

Shahed A \& Young KA 2013 Anti-Mullerian hormone (AMH), inhibin-alpha, growth differentiation factor 9 (GDF9), and bone morphogenic protein-15 (BMP15) mRNA and protein are influenced by photoperiod-induced ovarian regression and recrudescence in Siberian hamster ovaries. Molecular Reproduction and Development $\mathbf{8 0}$ 895-907. (doi:10.1002/mrd.22215)

Shi Y \& Massague J 2003 Mechanisms of TGF-beta signaling from cell membrane to the nucleus. Cell 113 685-700. (doi:10.1016/S0092 8674(03)00432-X)

Tarin JJ, Garcia-Perez MA \& Cano A 2014 Assisted reproductive technology results: why are live-birth percentages so low? Molecular Reproduction and Development 81 568-583. (doi:10.1002/mrd.22340) te Velde ER \& Pearson PL 2002 The variability of female reproductive ageing. Human Reproduction Update 8 141-154. (doi:10.1093/ humupd/8.2.141)

Tingen CM, Bristol-Gould SK, Kiesewetter SE, Wellington JT, Shea L \& Woodruff TK 2009 Prepubertal primordial follicle loss in mice is not due to classical apoptotic pathways. Biology of Reproduction 81 16-25. (doi:10.1095/biolreprod.108.074898)

Ueno S, Kuroda T, Maclaughlin DT, Ragin RC, Manganaro TF \& Donahoe PK 1989 Mullerian inhibiting substance in the adult rat ovary during various stages of the estrous cycle. Endocrinology 125 1060-1066. (doi:10.1210/endo-125-2-1060)

van Houten EL, Themmen AP \& Visser JA 2010 Anti-Mullerian hormone $(\mathrm{AMH})$ : regulator and marker of ovarian function. Annales d'Endocrinologie 71 191-197. (doi:10.1016/j.ando.2010.02.016)

van Rooij IA, Bancsi LF, Broekmans FJ, Looman CW, Habbema JD \& te Velde ER 2003 Women older than 40 years of age and those with elevated follicle-stimulating hormone levels differ in poor response rate and embryo quality in in vitro fertilization. Fertility and Sterility 79 482-488. (doi:10.1016/S0015-0282(02)04839-2)

Visser JA \& Themmen AP 2014 Role of anti-Mullerian hormone and bone morphogenetic proteins in the regulation of FSH sensitivity. Molecular and Cellular Endocrinology 382 460-465. (doi:10.1016/j. mce.2013.08.012)

Visser JA, Olaso R, Verhoef-Post M, Kramer P, Themmen AP \& Ingraham HA 2001 The serine/threonine transmembrane receptor ALK2 mediates Mullerian inhibiting substance signaling. Molecular Endocrinology 15 936-945. (doi:10.1210/me.15.6.936)

Visser JA, Durlinger AL, Peters IJ, van den Heuvel ER, Rose UM, Kramer P, de Jong FH \& Themmen AP 2007 Increased oocyte degeneration and follicular atresia during the estrous cycle in anti-Mullerian hormone null mice. Endocrinology 148 2301-2308. (doi:10.1210/en.2006-1265)

Wai T, Ao A, Zhang X, Cyr D, Dufort D \& Shoubridge EA 2010 The role of mitochondrial DNA copy number in mammalian fertility. Biology of Reproduction 83 52-62. (doi:10.1095/biolreprod.109.080887)

Wallace WH \& Kelsey TW 2010 Human ovarian reserve from conception to the menopause. PLOS ONE 5 e8772. (doi:10.1371/journal.pone.0008772)

Wang P-Y, Koishi K, McGeachie AB, Kimber M, Maclaughlin DT, Donahoe PK \& McLennan IS 2005 Mullerian inhibiting substance acts as a motor neuron survival factor in vitro. PNAS 102 16421-16425. (doi:10.1073/pnas.0508304102)

Wang J, Dicken C, Lustbader JW \& Tortoriello DV 2009 Evidence for a Mullerian-inhibiting substance autocrine/paracrine system in adult human endometrium. Fertility and Sterility 91 1195-1203. (doi:10.1016/j.fertnstert.2008.01.028)

Warburton D 1989 The effect of maternal age on the frequency of trisomy: change in meiosis or in utero selection? Progress in Clinical Biological Research 311 165-181.

Weenen C, Laven JS, Von Bergh AR, Cranfield M, Groome NP, Visser JA, Kramer P, Fauser BC \& Themmen AP 2004 Anti-Mullerian hormone expression pattern in the human ovary: potential implications for initial and cyclic follicle recruitment. Molecular Human Reproduction 10 77-83. (doi:10.1093/molehr/gah015)

Wordinger R, Sutton J \& Brun-Zinkernagel AM 1990 Ultrastructure of oocyte migration through the mouse ovarian surface epithelium during neonatal development. Anatomical Record 227 187-198. (doi:10.1002/ar.1092270207)

Zhang H \& Liu K 2015 Cellular and molecular regulation of the activation of mammalian primordial follicles: somatic cells initiate follicle activation in adulthood. Human Reproduction Update $\mathbf{2 1}$ 779-786. (doi:10.1093/humupd/dmv037)

Received in final form 7 December 2016

Accepted 24 January 2017

Accepted Preprint published online 27 January 2017 http://joe.endocrinology-journals.org

DOI: 10.1530/JOE-16-0522
๑ 2017 Society for Endocrinology Printed in Great Britain 